\title{
The Effect of Gastronomy Brand Value Components on Travel Intention: A Case of a Route*
}

Araştırma Makalesi / Research Article

\author{
Sibel OĞUZ ${ }^{1}$ \\ Murat İsmet HASEKİ ${ }^{2}$ \\ Zafer BUZCU ${ }^{3}$
}

\begin{abstract}
The aim of this research is to determine the effect of brand image, perceived quality, brand awareness and brand loyalty components on the travel intention which constitutes gastronomic brand value. Within the scope of the research, questionnaires were applied to local tourists in Adana, Mersin and Hatay, who stand out with their culinary culture and gastronomy resources. According to correlation analysis, the brand size that has the strongest relationship with travel intention was brand loyalty for Adana province (.738), brand awareness size for Mersin (.666) and brand loyalty size for Hatay (.757). Brand loyalty, brand awareness and brand image dimensions have a positive effect on travel intention for Adana and Mersin provinces. For the province of Hatay, it was determined that only the brand loyalty dimension had a positive effect on travel intention.
\end{abstract}

Keywords: Gastronomy Tourism, Brand Value, Brand Components, Travel Intention. JEL Codes: Z30, M30

\section{Gastronomi Marka Değeri Bileșenlerinin Seyahat Niyeti Üzerine Etkisi: Bir Rota Örneği}

ÖZ: Bu araştırmanın amacı gastronomi marka değerini oluşturan marka imajl, algllanan kalite, marka farkındalı̆̆ ve marka sadakati bileşenlerinin seyahat niyeti üzerindeki etkisinin belirlenmeye çalışılmasıdır. Araştırma kapsamında mutfak kültürü ve gastronomi kaynakları ile öne çıkan Adana, Mersin ve Hatay illerinde yerli turistlere anket uygulanmıştır. Korelasyon analizine göre göre seyahat niyeti ile en güçlü ilişkiye sahip olan marka boyutunun Adana ili için marka sadakati (.738), Mersin için marka farkındalığı boyutu (.666) ve Hatay için marka sadakati boyutu (.757) olduğu belirlenmişstir. Adana ve Mersin illeri için marka sadakati, marka farkındalı̆̆ ve marka imajı boyutları seyahat niyeti üzerinde pozitif etkiye sahiptir. Hatay ili için ise sadece marka sadakati boyutunun seyahat niyeti üzerinde pozitif bir etkiye sahip olduğu belirlenmiştir.

Anahtar Kelimeler: Gastronomi Turizmi, Marka Değeri, Marka bileşenleri, Seyahat Niyeti. JEL Codes: Z30, M30

\footnotetext{
* Supported by Adana Alparslan Türkeş Science and Technology University, Coordination of Scientific Research Projects (Project No: 18113010).

${ }^{1}$ Dr. Associate Professor, Adana Alparslan Türkeş Science and Technology University, soguz@atu.edu.tr, orcid.org/0000-0002-1951-3821.

${ }^{2}$ Dr. Associate Professor, Çukurova University, mhaseki@cu.edu.tr, orcid.org/0000-0002-1461-7285.

${ }^{3}$ Dr. Lecturer, Çukurova University, zbuzcu@cu.edu.tr, orcid.org/0000-0002-8379-762X.
} 


\section{Introduction}

Developments such as liberalization of service trade, competition among touristic destinations, developments in information, communication technologies, and increased awareness of travel have made the tourism industry the most important branch of the service industry. It is seen that the destinations within the tourism industry are working towards brand studies by adopting a customer-oriented marketing approach in order to differentiate themselves and get a share from this competition. The presence of many product and service groups to replace each other in the market has enabled brand studies to gain importance. In an increasingly competitive environment, every country, region or destination has to differentiate itself from its competitors with a unique product. The reason for the branding efforts of destinations is to create attraction to increase the number of tourists and income from tourists, create tourist loyalty and ensure that they return to destinations again.

The desire of tourists to search for new and unique experiences and alternative forms of tourism has made gastronomy, which is evaluated within the scope of cultural tourism, one of the most important reasons for visiting (Rand and Heat, 2006: 210). While the local food culture in a destination is considered as a cultural heritage for the destination, it is considered as one of the most valuable attractions of the destination within the scope of gastronomic tourism (Cohen and Avieli, 2004: 758-767; Mckercher et al., 2008). While touristic destinations around the world compete with each other in order to attract tourists, they create attraction with food and beverage diversity and gastronomic culture (Sims, 2009: 322) and try to make food and beverages a source of attraction by branding (Lai et al., 2018: 579). Food and beverages are among the most important touristic activities for tourists (Selwood, 2003: 179) and are considered as one of the most important elements contributing to the brand image (Lai et al., 2017). Researches show that there is a strong relationship between the food and beverage brand image created in the eyes of the tourist for the destination and visiting or revisiting a place (Rimmington and Yüksel, 1998; Kivela and Crotts, 2006; Karim and Chi, 2010; Lai et al., 2018).

While gastronomy is often regarded as the target part of a destination visit (Rand and Heat, 2006: 210), it contributes greatly to the destinations, in addition to strengthening local identity and culture (Hall and Sharples, 2003: 25-26). The first role of the food and beverage branding activities of the destination is the commercial effects provided by a unique brand image, and secondly cultural effects (Askegaard and Kjeldgaard, 2007: 145). For these reasons, the use of gastronomic resources in destination branding is of great importance for the destination.

Turkey, like other countries' cuisines, has many original dishes and beverages to offer to the world cuisine. Turkish cuisine (Çetin, 1993), which is among the three biggest cuisines of the world, has the potential to create attraction with its food 
and beverage richness. Considering the gastronomic resources, it has and the diversity of these resources, Turkey, on the basis of both the country and the region has a high potential. In recent years, it is seen that promotion and branding studies for Turkish cuisine have increased (Küçükaltan, 2009).

The purpose of this study is to investigate the impact of brand components directed towards gastronomy sources, which is one of the major tourist attraction for Turkey, such as brand image, brand awareness and perceived quality on travel intention of tourists. Therefore, Adana, Mersin and Hatay considered as Turkey's most important gastronomic routes with a gastronomic brand value have been assessed within the scope of the research. The study will contribute to the academic literature in the field of tourism as well as examine the effects of brand components on the travel intention of the tourists and show the relationship status between them.

\section{Conceptual Framework and Hypotheses}

Travel intention, as a travel motivation, is called a series of needs group that enable people to travel before they travel (Kao et al., 2008: 18). Travel motivation is an effective indicator of tourist behavior, because the trend/intention of tourists significantly influences their future travel decisions (Horng et al., 2012: 816). Gastronomic resources are one of the most important visiting reasons for tourists that affect their travel intentions (Rand and Heat, 2006: 210). In this regard, while local food and beverages are a kind of important attraction for the tourists visiting the destination (Hacioğlu et al., 2009), the brand image of the destination on gastronomy also significantly affects the travel intention of tourists. In the studies, it is seen that the gastronomic brand image of the destination has a positive effect on travel intentions (Kivela and Crotts, 2006; Ling et al., 2010; SanchezCanizares and Lopez-Guzman, 2012).

While brand value is seen as a consumer's thought about the product or service, it also refers to the value added to that product and/or service. Brand value is expressed as the group of active and passive assets related to the brand name and symbol, which increases or decreases the value provided to a firm or customers (Yapraklı and Kara, 2015: 136). Brand value is important for a tourist destination to increase the number of tourists and tourism revenues and to compete (Molina et al., 2019: 114). There are some components that make up the brand value. The most used brand value components are expressed as brand loyalty, brand awareness, brand image and perceived quality (Horng et al., 2012: 816; Kocaman and Güngör, 2012: 147; Yapraklı and Kara, 2015: 136; Chi et al., 2019: $2^{\text {nd }}$ ).

Brand loyalty is an essential component of brand value. Brand loyalty is expressed as a positive situation that results in repurchase if a consumer is satisfied with the brand that she/he has previously purchased (for goods and services) (Kocaman and Güngör, 2012: 148). Brand loyalty for a branding destination in gastronomy ensures that tourists come back to that destination. In 
this regard, it is seen as the tourist's commitment to that destination (Chi et al., 2019: 3). Brand loyalty provides a great benefit to the destination for a tourist to visit that destination again and recommend it to others (friend, relative, friend etc.). Brand loyalty has a positive effect on tourists' travel intention (Horng et al., 2012: 817). In the light of this information, the hypothesis regarding the relationship between brand loyalty and travel intention was created as follows:

H1: Tourists' brand loyalty has a significant and positive relationship with travel intention.

Brand awareness is about the possibility of consumers to remember and be aware of a brand. In this respect, it constitutes a special and necessary aspect of brand value (Chi et al., 2019: 2). Brand awareness shows the power of the brand in mind of consumers. While brand awareness is considered as the main component of the impact of a brand in the tourism industry, it affects the purchasing decision of the consumer (Boo et al., 2009: 221). It is stated that there is a positive relationship between the awareness of a brand and the future travel intention (Horng et al., 2012: 817). In the light of this information, the hypothesis regarding the relationship between brand awareness and travel intention was created as follows:

H2: Tourists' brand awareness has a significant and positive relationship with travel intention.

Brand image can be explained as the perception of a product or service, together with the determining factors such as the personality of that product or service and the connotations it creates in the minds of consumers (Ceylan, 2011: 92). Brand image, which is an important factor in being perceived positively by the consumers, being preferred and competitiveness, is defined as the sum of the features that consumers identify with the product and the impressions of consumers about the product (Kocaman and Güngör, 2012: 147). The fact that the tourism regions have a brand image has a positive effect on the preference of the regions (Kozak, 2008: 139-140). Many destinations have started branding their own food and beverages and started using it as a tourist attraction. It is important to create an attractive and different image of gastronomy for a destination (Lai et al., 2018: 579). The image of a gastronomy created for a destination not only affects the intentions of the tourists before travel, but also increases the competitiveness with rival destinations (Murphy et al., 2007; Chang and Mak, 2018; Chi et al., 2019: 2). In this regard, studies show that the gastronomy image of a destination positively affects the intention to travel (Karim and Chi, 2010; Yu and Sun, 2019: 258; Pineda et al., 2019: 1). In addition, there is also an increase in the consumption rate of a food or beverage with a gastronomic brand image in a destination (Ryan and Casidy, 2018: 239). In the light of this information, the hypothesis regarding the relationship between brand image and travel intention was created as follows: 
H3: Brand image has a significant and positive relationship with the travel intention of tourists.

Perceived Quality is expressed as the consumer's assessment of the overall excellence and superiority of a product or service (Zeithaml, 1988: 3). Perceived quality has an impact on a consumer's purchase decisions for a product or service (Wang et al., 2019: 1). The perceived quality adds value to the brand and the branding process with contributions such as creating intention to buy, creating the basis for brand extension and creating consumer interest. In this regard, perceived quality has an impact on brand value (Kocaman and Güngör, 2012: 148-159). Expectations regarding the quality level of the service/product to be provided and the gastronomic identity and image of a destination are important. (Çalışkan, 2013: 45). Perceived quality has a direct interest in behavioral intentions (travel intention, purchase, etc.) (Chow et al., 2007). Destinations that create a perception of quality and have gastronomic values make important contributions to their promotion, development and gastronomic identities. In this respect, while the high perceived quality of the destination's gastronomy affects travel intentions positively, it also contributes to tourist loyalty, recommending the destination to others and intending to travel again (Fernandez et al., 2019: 2-3). In the light of this information, the hypothesis regarding the relationship between perceived quality and travel intention was created as follows:

H4: Perceived quality has a significant and positive relationship with the travel intention of tourists.

\section{Method of the Research}

In this study, firstly, it is aimed to reveal the brand value of Adana, Mersin and Hatay destinations, which are assumed to have an important potential in terms of gastronomic assets, within the framework of the dimensions that make up the brand value. The effect of the brand image, perceived quality, brand awareness and brand loyalty components that make up the brand value on the travel intention was tried to be determined. Through the study, it was aimed to determine which of the expressions related to the brand value dimensions and travel intention of the visitors are perceived as priority. With this study, the first contribution will be made to the literature by determining the gastronomy brand value components of Adana, Mersin and Hatay provinces, and the second contribution will be made by determining their effects on travel intention. Its original value is to put forward a study for the first time on the route of these provinces. The research model created in this direction is shown in Figure 1 as follows:

Figure 1: Research Model

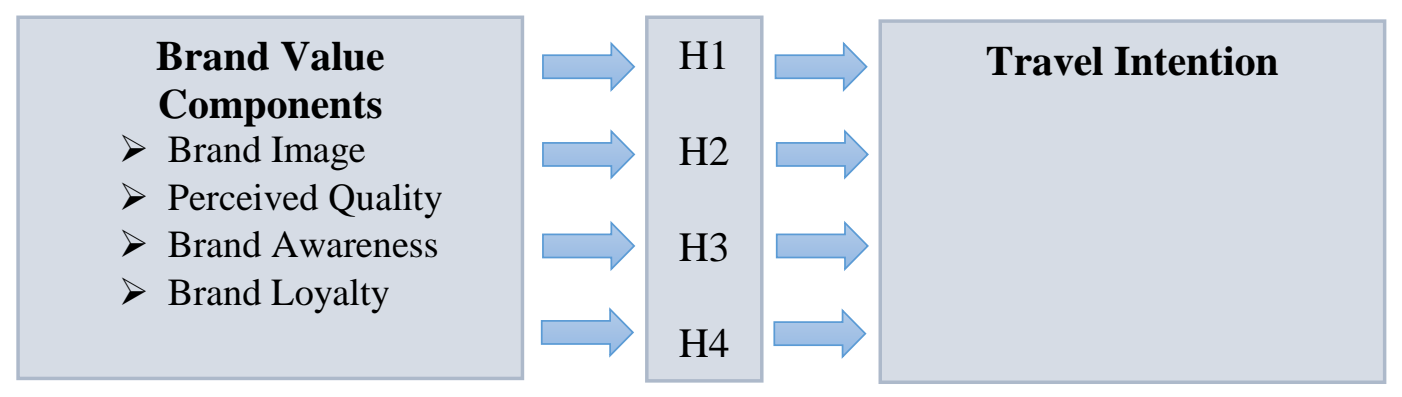




\subsection{Universe and Sample of the Research}

The research universe consists of local tourists visiting Adana, Mersin and Hatay provinces and the questionnaire was implemented between $1^{\text {st }}$ March $2019-1^{\text {st }}$ October 2019. The number of local tourists was determined according to the data obtained from the Provincial Directorate of Culture and Tourism. According to 2019 data, including October, 713.856 local tourists in Adana province, according to 2018 data, 1 million 123 in Mersin province and 423.303 in Hatay province were accommodated. There are different methods used in the literature to determine the number of samples. According to Altunışık et al. (2007: 127), in the case of $95 \%$ confidence interval and 0.05 sample error, the number of samples that should be used for research universe for each province is 384 . The reason for choosing the provinces mentioned in the research is that they are rich in gastronomic resources and there are activities in the field of gastronomy in these provinces. The reason for choosing domestic tourists as an example is the assumption that domestic tourists have more information about the culinary culture and gastronomy elements in these provinces than foreign tourists and they will give more consistent answers in this regard.

\subsection{Method and Tool of Collecting Research Data}

Questionnaire technique, one of the quantitative research methods, was used in collecting data. In order to prepare the research scale, the scales developed as a result of the literature review and which are clearly shown in Table 1 were used to investigate the impact on brand value and travel intention. In order to determine the descriptive characteristics of the participants in the created scale, five questions were asked. Propositions consisting of 38 expressions for dimensions of brand value and 3 for dimension of travel intention were used. The scale was created as (1) Strongly Disagree - (5) Strongly Agree for the propositions of brand value and travel intention.

Table 1: Scales Used

\begin{tabular}{lc}
\hline \multicolumn{1}{c}{ Authors } & Item Number \\
\hline Horng et al. (2012) & 29 \\
Çetinsöz and Artuğer (2013) & 6 \\
Boo et al. (2009) & 5 \\
Amira (2009) & 1 \\
Total & 41 \\
\hline
\end{tabular}

\subsection{Process of Data Collection}

In order to ensure the content validity of the expressions in the prepared scale, it was sent to ten academicians who are experts in the field of tourism and asked for evaluation. In accordance with the suggestions made by the experts, the scale of which meaning ambiguities were eliminated was applied on the sample. The scale was applied between the dates of $1^{\text {st }}$ March $2019-1^{\text {st }}$ October 2019 with the convenience sampling method. 383 questionnaires in Adana province, 394 in 
Mersin province and 448 in Hatay province were implemented by face to face with local tourists. After multivariate normal distribution and deviation analysis, 371 questionnaires for Adana, 388 for Mersin and 376 for Hatay were analyzed.

\subsection{Reliability Analysis}

Cronbach's Alpha was used to test the reliability of the scale. According to the reliability analysis results; Cronbach's Alpha is .933 for the entire scale, .889 for the first half of the scale and .878 for the second half of the scale. These values show that the scale is highly reliable. Cronbach's Alpha coefficients of all provinces are given in Table 2 below. When these values in Table 2 are examined, it is seen that all scales are reliable.

Table 2: Reliability Values for the Scale

\begin{tabular}{lcccc}
\hline Dimension & $\begin{array}{c}\text { Number of } \\
\text { Expressions }\end{array}$ & $\begin{array}{c}\text { Adana } \\
\text { Cronbach } \\
\text { Alpha } \\
\text { Coefficient }\end{array}$ & $\begin{array}{c}\text { Mersin } \\
\text { Cronbach } \\
\text { Alpha } \\
\text { Coefficient }\end{array}$ & $\begin{array}{c}\text { Cronbach } \\
\text { Alpha } \\
\text { Coefficient }\end{array}$ \\
\hline Brand Image & 12 & .974 & .894 & .971 \\
Perceived Quality & 14 & & & \\
Brand Awareness & 6 & & & \\
Brand Loyalty & 6 & & & \\
Travel Intention & 3 & & & \\
Total & 41 & & & \\
\hline
\end{tabular}

\section{Research Findings and Discussion}

\subsection{Findings Regarding the Participants}

Information about the participants of Adana, Mersin and Hatay provinces are presented in the tables below (Tables 3, 4, and 5).

Descriptive information about the participants of Adana province are given in Table 3. It is seen that $80.3 \%$ of the participants in the study are men. When the distribution is analyzed in terms of age groups, the 21-30 age group is the highest number of visitors of Adana with 40.9\%. The age group with the visitors aged 61 and over is determined as the minimum number with $3.5 \%$. When the education levels of the participants are analyzed, it is seen that those who have secondary education constitute the highest number of visitors with $42.31 \%$, while those who have graduate education constitute the minimum number of visitors with $1.6 \%$. It is seen that $24.3 \%$ of the participants in the research are workers, while $23 \%$ are students. When the reasons of the participants to travel to Adana are examined, it is seen that while the visitors who came for relative-friend visit are the first place with $46.6 \%$, the visitors who came for gastronomy are in the last place with $0.3 \%$.

Descriptive information about the participants of Mersin province are given in Table 4 . It is seen that $62.6 \%$ of the participants in the study are men. When the distribution is analyzed in terms of age groups, it is seen that the 21-30 age group 
is the highest number of visitors of Mersin with $40.9 \%$, while the age group with the visitors aged 61 and over is determined as the minimum number with $2.1 \%$. When the education levels of the participants are analyzed, it is seen that those who have primary + secondary education constitute the highest number of visitors with $83.5 \%$, and those who have undergraduate education constitute the minimum number of visitors with $3,1 \%$. It is seen that while $40.5 \%$ of the participants in the study are workers, $23.7 \%$ are self-employed. When the reasons for the participants to travel to Mersin are examined, it is seen that the visitors who come for relativefriend visit are in the first place with $46.6 \%$, while the visitors who come for the purpose of health are in the last place with $2.1 \%$.

Table 3: Information regarding the participants of Adana Province $(n=371)$

$\begin{array}{lcllcc}\text { Variable } & \begin{array}{c}\text { Frequency } \\ \text { Gender }\end{array} & \mathbf{\%} & \text { Variable } & \begin{array}{c}\text { Frequency } \\ \text { Profession }\end{array} & \text { \% } \\ \text { Female } & 71 & 19.1 & \text { Worker } & 89 & 24 \\ \text { Male } & 298 & 80.3 & \text { Officer } & 16 & 4.3 \\ \text { Total } & \mathbf{3 7 1} & \mathbf{1 0 0} & \text { Self-employed } & 100 & 27 \\ & \text { Age } & & \text { Instructor } & 14 & 3.8 \\ 20 \text { and below } & 55 & 14.8 & \text { Doctor } & 1 & 0.3 \\ 21-30 & 152 & 40.9 & \text { Housewife } & 23 & 6.2 \\ 31-40 & 65 & 17.5 & \text { Retired } & 23 & 6.2 \\ 41-50 & 48 & 12.9 & \text { Engineer/Architect } & 5 & 1.3 \\ 51-60 & 38 & 10.2 & \text { Unemployed } & 10 & 2.7 \\ \text { 61 and above } & 13 & 3.5 & \text { Student } & 86 & 23.2 \\ \text { Total } & \mathbf{3 1 7} & \mathbf{1 0 0} & \text { Cook } & 4 & 1.1 \\ & & & \text { Total } & \mathbf{3 7 1} \\ \text { Primary Edu. } & 60 & & & \text { Reason of Visit } & \\ \text { Secondary Edu. } & 157 & 16.2 & \text { Entertainment-Rest } & 57 & 15.4 \\ \text { Associate } & 75 & 42.31 & \text { Relative-Friend visit } & 173 & 46.6 \\ \text { Undergraduate } & 73 & 20.2 & \text { Culture } & 4 & 1.1 \\ \text { Graduate } & 6 & 19.7 & \text { Business } & 92 & 24.8 \\ \text { Total } & \mathbf{3 7 1} & 1.6 & \text { Education } & 27 & 7.3 \\ & & \mathbf{1 0 0} & \text { Health } & 12 & 3.2 \\ & & & \text { Gastronomy } & 1 & 0.3 \\ & & & \text { Sports } & 5 & 1.3 \\ & & & \text { Total } & \mathbf{3 7 1} & \mathbf{1 0 0}\end{array}$

Descriptive information about the participants of Hatay province are given in Table 5. It is seen that $54.5 \%$ of the participants in the study are women. When the distribution is analyzed in terms of age groups, it is seen that the 21-30 age group is the highest number of visitors of Hatay with $37.8 \%$, while the age group with the visitors aged 61 and over is determined as the minimum number with $5.6 \%$. When the education levels of the participants are analyzed, it is seen that while the ones who have undergraduate education constitute the highest number of visitors with $50.3 \%$, those who have graduate education constitute the minimum number of visitors with $4.3 \%$. It is seen that while $30.3 \%$ of the participants in the study are bank workers, $26.6 \%$ are students. When the reasons for the participants to travel to Hatay are examined, it is seen that the visitors who 
come for entertainment and are in the first place with $26.6 \%$, while the visitors who come for the purpose of sports are in the last place with $0.3 \%$.

Table 4: Information regarding the participants of Mersin Province $(n=388)$

$\begin{array}{lcllcl}\text { Variable } & \begin{array}{c}\text { Frequency } \\ \text { Gender }\end{array} & \mathbf{\%} & \text { Variable } & \begin{array}{c}\text { Frequency } \\ \text { Profession }\end{array} & \text { \% } \\ \text { Female } & 145 & 37.4 & \text { Worker } & 157 & 40.5 \\ \text { Male } & 243 & 62.6 & \text { Officer } & 6 & 1.5 \\ \text { Total } & \mathbf{3 8 8} & \mathbf{1 0 0} & \text { Self-employed } & 92 & 23.7 \\ & \text { Age } & & \text { Instructor } & 6 & 1.5 \\ 20 \text { and below } & 3 & 0.8 & \text { Housewife } & 71 & 18.3 \\ 21-30 & 163 & 42 & \text { Retired } & 7 & 1.8 \\ 31-40 & 129 & 33.2 & \text { Engineer/Architect } & 2 & 0.5 \\ 41-50 & 70 & 18 & \text { Psychologist } & 1 & 0.3 \\ 51-60 & 15 & 3.9 & \text { Unemployed } & 46 & 11.9 \\ \text { 61 and above } & 8 & 2.1 & \text { Total } & 388 & 100 \\ \text { Total } & \mathbf{3 8 8} & \mathbf{1 0 0} & & & \\ & & & & \text { Reason of Visit } & \\ \text { Primary Edu. } & \mathbf{E d u c a t i o n} & & & 181 & 46.6 \\ \text { Secondary Edu. } & 158 & 42.8 & \text { Entertainment-Rest } & 49 \\ \text { Associate } & 52 & 40.7 & \text { Relative-Friend visit } & 190 & 2.3 \\ \text { Undergraduate } & 12 & 13.4 & \text { Business } & 9 & 2.1 \\ \text { Total } & \mathbf{3 8 8} & 3,1 & \text { Health } & 8 & \mathbf{1 0 0}\end{array}$

Table 5: Information regarding the participants of Hatay Province $(\mathrm{n}=376)$

\begin{tabular}{|c|c|c|c|c|c|}
\hline Variable & $\begin{array}{l}\text { Frequency } \\
\text { Gender }\end{array}$ & $\%$ & Variable & $\begin{array}{l}\text { Frequency } \\
\text { ession }\end{array}$ & $\%$ \\
\hline Female & 205 & 54.5 & Worker & 8 & 2.1 \\
\hline Male & 171 & 45.5 & Officer & 32 & 8.5 \\
\hline \multirow{2}{*}{ Total } & 376 & 100 & Self-employed & 5 & 1.3 \\
\hline & Age & & Instructor & 69 & 18.4 \\
\hline 20 and below & 33 & 8.8 & Doctor & 3 & 0.8 \\
\hline $21-30$ & 142 & 37.8 & Housewife & 19 & 5.1 \\
\hline $31-40$ & 118 & 31.4 & Retired & 10 & 2.7 \\
\hline $41-50$ & 44 & 11.7 & Engineer/Architect & 10 & 2.7 \\
\hline $51-60$ & 18 & 4.8 & Psychologist & 3 & 0.8 \\
\hline 61 and above & 21 & 5.6 & Academician & 3 & 0.8 \\
\hline \multirow{4}{*}{ Total } & 376 & 100 & Student & 100 & 26.6 \\
\hline & & & Bank Worker & 114 & 30.3 \\
\hline & & & Total & 376 & 100 \\
\hline & ducation & & \multicolumn{3}{|c|}{ Reason of Visit } \\
\hline Primary Edu. & 20 & 5.3 & Entertainment-Rest & 100 & 26.6 \\
\hline Secondary Edu. & 69 & 18.4 & Relative-Friend visit & 44 & 11.7 \\
\hline Associate & 82 & 21.8 & Culture & 42 & 11.2 \\
\hline Undergraduate & 189 & 50.3 & Business & 70 & 18.6 \\
\hline Graduate & 16 & 4.3 & Education & 37 & 9.8 \\
\hline \multirow[t]{5}{*}{ Total } & 376 & 100 & Health & 8 & 2.1 \\
\hline & & & Gastronomy & 35 & 9.3 \\
\hline & & & Feast & 39 & 10.4 \\
\hline & & & Sports & 1 & 0.3 \\
\hline & & & Total & 376 & 100 \\
\hline
\end{tabular}


Table 6 shows the arithmetic mean and standard deviations of the participants' responses to brand image, perceived quality, brand awareness, brand loyalty, which are the sub-dimensions of the brand value, and to travel intention. The answers are divided into the obtained dimensions by the literature review.

Table 6: Arithmetic Mean (A.M.) and Standard Deviations (S.D.) of Expressions and Dimensions

\begin{tabular}{|c|c|c|c|c|c|c|}
\hline & \multicolumn{2}{|c|}{ ADANA } & \multicolumn{2}{|c|}{ MERSÍN } & \multicolumn{2}{|c|}{ HATAY } \\
\hline & A.M. & S.D. & A.M. & S.D. & A.M. & S.D. \\
\hline BRAND IMAGE & 3.78 & - & 4.08 & - & 4.22 & - \\
\hline $\begin{array}{l}\text { 1. The province has a relaxing dining } \\
\text { atmosphere. }\end{array}$ & 3.86 & .843 & 4.26 & .573 & 4.12 & .975 \\
\hline 2. The province has a rich culinary culture. & 3.99 & .769 & 4.02 & .800 & 4.47 & .829 \\
\hline 3. The provincial kitchen is quite diverse. & 3.88 & .753 & 4.05 & .735 & 4.48 & .810 \\
\hline $\begin{array}{l}\text { 4. Visiting the province is a great } \\
\text { opportunity to try the kitchen. }\end{array}$ & 3.93 & .783 & 4.21 & .748 & 4.50 & .759 \\
\hline $\begin{array}{l}\text { 5. There are many districts suitable for } \\
\text { gastronomy tourism in the province. }\end{array}$ & 3.74 & .879 & 4.07 & .648 & 3.91 & 1.019 \\
\hline $\begin{array}{l}\text { 6. There are excellent dining opportunities } \\
\text { in the province. }\end{array}$ & 3.90 & .795 & 3.99 & .761 & 4.35 & .796 \\
\hline $\begin{array}{l}\text { 7. Food service staff is very friendly in the } \\
\text { province. }\end{array}$ & 3.93 & .783 & 4.14 & .670 & 4.11 & .943 \\
\hline 8. The provincial kitchen is unique. & 3.84 & .830 & 4.07 & .735 & 3.79 & 1.155 \\
\hline 9. The province offers attractive food. & 3.67 & .898 & 4.01 & .691 & 4.26 & .813 \\
\hline $\begin{array}{l}\text { 10. When I visit the city, it is effective that I } \\
\text { like the provincial kitchen and it reflects } \\
\text { me. }\end{array}$ & 2.85 & 1.353 & 4.03 & .648 & 4.18 & .980 \\
\hline 11. The city offers attractive snacks. & 3.87 & .787 & 4.03 & .662 & 4.27 & .882 \\
\hline $\begin{array}{l}\text { 12. My food experience in the province is } \\
\text { consistent with my impression of } \\
\text { culinary culture. }\end{array}$ & 4.04 & .806 & 4.08 & .638 & 4.28 & .991 \\
\hline PERCEIVED QUALITY & 3.96 & - & 4.07 & - & 4.23 & - \\
\hline 13. The province offers delicious food. & 3.94 & .828 & 4.32 & .515 & 4.50 & .741 \\
\hline 14. The province offers high quality food. & 4.00 & .787 & 4.24 & .791 & 4.27 & .867 \\
\hline $\begin{array}{l}\text { 15. If we look at the current possibilities of } \\
\text { the provincial cuisine, it is possible to } \\
\text { say that it may improve in the future. }\end{array}$ & 3.93 & .789 & 3.98 & .690 & 4.21 & 1.029 \\
\hline $\begin{array}{l}\text { 16. Provincial cuisine is better than similar } \\
\text { places. }\end{array}$ & 3.95 & .757 & 3.96 & .744 & 4.15 & .889 \\
\hline $\begin{array}{l}\text { 17. The province offers an excellent quality } \\
\text { in gastronomy tourism. }\end{array}$ & 3.92 & .764 & 4.09 & .656 & 4.13 & .920 \\
\hline 18. Provincial food environment is clean. & 3.95 & .775 & 4.13 & .698 & 4.06 & .957 \\
\hline $\begin{array}{l}\text { 19. The province offers affordable prices in } \\
\text { gastronomy tourism. }\end{array}$ & 3.99 & .793 & 4.02 & .719 & 3.77 & 1.136 \\
\hline $\begin{array}{l}\text { 20. The province provides a good quality in } \\
\text { restaurant services. }\end{array}$ & 3.93 & .773 & 4.01 & .730 & 4.12 & .858 \\
\hline $\begin{array}{l}\text { 21. I recommend the dishes of the region I } \\
\text { ate in the province to others. }\end{array}$ & 3.95 & .766 & 4.06 & .683 & 4.38 & .767 \\
\hline
\end{tabular}


22. Local dishes I ate in the province were clean and delicious.

$\begin{array}{lllllll}\text { 23. The local dishes I ate in the province are } & 4.00 & .794 & 4.05 & .691 & 4.33 & .869\end{array}$ suitable for my personality and belief.

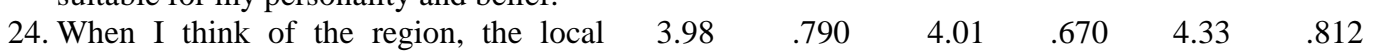
dishes I ate in the province immediately come to my mind.

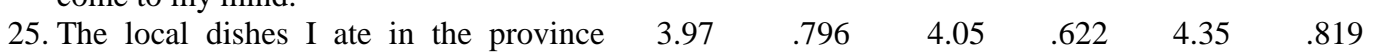
made me recognize and understand the culture of the region.

$\begin{array}{lllllll}\text { 26. Local dishes that I ate in the province are } & 4.01 & .783 & 4.07 & .617 & 4.39 & .802\end{array}$ an important factor for the branding of the region.

\begin{tabular}{|c|c|c|c|c|c|c|}
\hline BRAND AWARENESS & 4.05 & - & 4.16 & - & 4.28 & - \\
\hline $\begin{array}{l}\text { 27. The provincial kitchen has a good } \\
\text { reputation. }\end{array}$ & 4.02 & .790 & 4.22 & .511 & 4.40 & .829 \\
\hline $\begin{array}{l}\text { 28. I can easily say the famous dishes of the } \\
\text { province. }\end{array}$ & 4.01 & .814 & 4.15 & .828 & 4.31 & .848 \\
\hline $\begin{array}{l}\text { 29. When I think about gastronomy, the } \\
\text { provincial cuisine comes to my mind } \\
\text { immediately. }\end{array}$ & 4.03 & .825 & 4.04 & .548 & 4.24 & .866 \\
\hline 30. The province has a good name and fame. & 4.16 & .810 & 4.00 & .680 & 4.36 & .898 \\
\hline $\begin{array}{l}\text { 31. Some features of the province come to } \\
\text { my mind immediately. }\end{array}$ & 4.09 & .771 & 4.19 & .436 & 4.22 & .806 \\
\hline $\begin{array}{l}\text { 32. I immediately notice the name of the } \\
\text { province among other destinations. }\end{array}$ & 4.03 & .783 & 4.39 & .765 & 4.17 & .860 \\
\hline BRAND LOYALTY & 4.00 & - & 4.13 & - & 4.32 & - \\
\hline 33. I generally trust the provincial kitchen. & 4.02 & .790 & 4.33 & .592 & 4.38 & .821 \\
\hline $\begin{array}{l}\text { 34. I would recommend others to visit the } \\
\text { province for gastronomy tourism. }\end{array}$ & 4.00 & .761 & 4.04 & .794 & 4.46 & .782 \\
\hline $\begin{array}{l}\text { 35. I like to visit the province for } \\
\text { gastronomy tourism. }\end{array}$ & 4.03 & .802 & 4.10 & .640 & 4.32 & .854 \\
\hline $\begin{array}{l}\text { 36. I recommend the province as a } \\
\text { gastronomic place. }\end{array}$ & 3.94 & .745 & 4.20 & .701 & 4.35 & .867 \\
\hline $\begin{array}{l}\text { 37. I would like to visit the province again in } \\
\text { the future. }\end{array}$ & 4.03 & .756 & 4.06 & .628 & 4.34 & .884 \\
\hline $\begin{array}{l}\text { 38. If I come to this region again, this } \\
\text { province will be my first choice. }\end{array}$ & 3.98 & .812 & 4.06 & .630 & 4.10 & 1.056 \\
\hline TRAVEL INTENTION & 3.76 & - & 4.16 & - & 4.10 & - \\
\hline $\begin{array}{l}\text { 39. I would like to visit the province again } \\
\text { for gastronomy tourism. }\end{array}$ & 3.78 & .797 & 4.18 & .518 & 4.20 & .931 \\
\hline $\begin{array}{l}\text { 40. I can visit the province again for } \\
\text { gastronomy tourism next year. }\end{array}$ & 3.88 & .822 & 4.21 & .742 & 4.13 & .964 \\
\hline 41. I am planning to visit the province again & 3.64 & .869 & 4.12 & .561 & 3.98 & 1.129 \\
\hline
\end{tabular}
for gastronomy tourism next year.

Answer Categories: (1) Strongly Disagree; (2) Disagree; (3) Neither Disagree Nor Agree; (4) Agree; (5) Strongly Agree.

For Adana, participation is generally close to "I agree" (4) in line with the answers given by the visitors to the propositions regarding brand image, perceived quality, brand awareness and brand loyalty dimensions, which are sub-dimensions of brand value. Especially with regard to brand image, it was determined that the 
impression of the visitors about Adana's food experience and cuisine culture is consistent, and they think there is a rich food culture in Adana, traveling to Adana is a great opportunity to try the local cuisine, and the food service staff in Adana are very friendly. In addition, in terms of perceived quality, it was determined that the local dishes they eat in Adana are an important factor for the branding of the region and they think that Adana offers high quality dishes. In the light of the information that the participants who think that the city and its cuisine have a good reputation have brand awareness, they like to visit Adana for gastronomy tourism and they want to visit Adana again in the future, it is possible to say that the gastronomy brand value for Adana is in the foreground. In the part of travel intention to Adana, the expression that "I can visit Adana again for gastronomy tourism next year" is at the forefront. Participation is generally close to "I agree" (4) in line with the answers given by the visitors to their travel intentions. According to the arithmetic mean of the dimensions, it was determined that the brand awareness among all the gastronomy brand value dimensions was the most frequently cared dimension $(\mathrm{a} . \mathrm{m} .=4.05)$. This dimension is followed by brand loyalty with an average of 4.00 , perceived quality with an average of 3.96 , and brand image with an average of 3.78. Finally, it was determined that the dimension of travel intention has an average value of 3.76. While these values reveal that brand awareness and brand loyalty are more determinant in Adana destination gastronomy brand value dimensions, they also show that brand image and perceived quality are slightly behind other dimensions.

For Mersin, participation is generally above "Agree" (4) in line with the answers given by the visitors to the propositions regarding the brand image, perceived quality, brand awareness and brand loyalty dimensions which are sub-dimensions of brand value. It has become prominent in the image of the brand that especially Mersin has a relaxing dining atmosphere, the food service staff are very friendly and traveling to Mersin a great opportunity to try the cuisine of Mersin. In addition, visitors stated that Mersin offers delicious and high quality meals in terms of perceived quality. Participants, who think that the provincial cuisine had a good reputation, were found to immediately notice the name of Mersin among other destinations, thus it was determined that they have brand awareness. The fact that they generally trust Mersin cuisine and suggest Mersin as a gastronomic place shows that they have brand loyalty. Accordingly, it is seen that the gastronomy brand value for Mersin is at the forefront. Participation is generally above "I Agree" (4) in line with the answers they gave to their intention to travel. According to the arithmetic mean of the dimensions, it was determined that the brand awareness among the gastronomy brand value dimensions was the most frequently cared dimension $(\mathrm{a} . \mathrm{m} .=4.16)$. This dimension is followed by brand loyalty with an average of 4.13 , brand image with an average of 4,08 and perceived quality with an average of 4.07. Finally, it was determined that the dimension of travel intention has an arithmetic mean of 4.16. While these values reveal that brand awareness and brand loyalty are more determinant in Mersin 
destination gastronomy brand value dimensions, they also show that brand image and perceived quality are slightly behind other dimensions.

For Hatay, participation is generally close to "Strongly Agree" (5) in line with the answers given by the visitors to the propositions regarding the brand image, perceived quality, brand awareness and brand loyalty dimensions, which are subdimensions of brand value. It has come to the forefront in brand image dimension that visiting Hatay is a great opportunity to try its cuisine, its cuisine is diverse and it has a rich culinary culture. In terms of perceived quality, the explanations of the visitors that Hatay offers delicious food, the local food they ate in Hatay is an important factor for the branding of the region and the local food they ate in Hatay caused recognition and understanding of the region come forward. In terms of brand awareness, it has come to the fore that the provincial cuisine has a good reputation and the visitors can easily say the most famous Hatay dishes. It was observed that the participants, who stated that they trust Hatay cuisine and recommend to visit Hatay for gastronomy tourism, have brand loyalty. Accordingly, it is seen that the gastronomy brand value for Hatay is at the forefront. Participation is generally above "I Agree" (4) in line with the answers they gave to their intention to travel. According to the arithmetic mean of the dimensions, it was determined that the brand loyalty is the most cared dimension among the gastronomy brand value dimensions (a.m. $=4.32)$. This dimension is followed by brand awareness with an average of 4,28, quality perceived with an average of 4.23 , and brand image with an average of 4.22 . Finally, it was determined that the dimension of travel intention has an average value of 4.10. These values reveal that brand awareness and brand loyalty are more determinant in the Hatay destination gastronomy brand value dimensions, but also show that the brand image and perceived quality are slightly behind other dimensions.

\subsection{Correlation Analysis}

Correlation analysis was made in order to measure whether there is a relationship between dimensions of destination gastronomy brand value and dimension of travel intention. The results regarding the analysis made for each province are given in Table 7. The results of the analysis for Adana show that the dimension that has the strongest relationship with travel intention is the brand loyalty $(r=.738)$. The results of the analysis for Mersin show that the dimension that has the strongest relationship with travel intention is the brand awareness $(r=.666)$. The results of the analysis for Hatay province show that the dimension that has the strongest relationship with travel intention is the brand loyalty $(r=.757)$. 
Table 7: Correlation Analysis

\begin{tabular}{|c|c|c|c|c|c|}
\hline Adana $(n=371)$ & B. Image & P. Quality & B. Awareness & B. Loyalty & T. Intention \\
\hline B. Image & 1 & & & & \\
\hline P. Quality & $.913^{* *}$ & 1 & & & \\
\hline B. Awareness & $873^{* *}$ & $.896^{* *}$ & 1 & & \\
\hline B. Loyalty & $.836^{* *}$ & $.850^{* * *}$ & $.838^{* *}$ & 1 & \\
\hline T. Intention & $.692^{* *}$ & $652^{* *}$ & $.686^{* *}$ & $.738^{* *}$ & 1 \\
\hline \multicolumn{6}{|l|}{ Mersin $(n=388)$} \\
\hline B. Image & 1 & & & & \\
\hline P. Quality & $.835^{* *}$ & 1 & & & \\
\hline B. Awareness & $.762^{* *}$ & $.796^{* *}$ & 1 & & \\
\hline B. Loyalty & $.734^{* *}$ & $.746^{* *}$ & $.704^{* * *}$ & 1 & \\
\hline T. Intention & $.639^{* *}$ & $.615^{* *}$ & $.666^{* *}$ & $.608^{* *}$ & 1 \\
\hline \multicolumn{6}{|l|}{ Hatay $(n=376)$} \\
\hline B.I mage & 1 & & & & \\
\hline P. Quality & $.837^{* *}$ & 1 & & & \\
\hline B. Awareness & $.793^{* *}$ & $.806^{* *}$ & 1 & & \\
\hline B. Loyalty & $.781^{* *}$ & $.799^{* *}$ & $.790^{* *}$ & 1 & \\
\hline T. Intention & $.596^{* *}$ & $.641^{* *}$ & $.642^{* *}$ & $.757^{* * *}$ & 1 \\
\hline
\end{tabular}

$* * \mathrm{p}<0.01$

\subsection{Hypothesis Tests}

In line with the main purpose of the research, multiple linear regression analysis was carried out regarding the hypotheses created. The results of the analysis related to hypothesis testing are given for each province.

Table 8: Hypothesis Test Results Regarding Provinces

\begin{tabular}{|c|c|c|c|c|c|c|c|c|c|}
\hline \multirow[t]{2}{*}{$\begin{array}{l}\text { Independent } \\
\text { Variables }\end{array}$} & \multicolumn{3}{|c|}{$\begin{array}{l}\text { Dependent Variable } \\
\text { Travel Intention } \\
\text { (Adana province) }\end{array}$} & \multicolumn{3}{|c|}{$\begin{array}{l}\text { Dependent Variable } \\
\text { Travel Intention } \\
\text { (Mersin province) }\end{array}$} & \multicolumn{3}{|c|}{$\begin{array}{l}\text { Dependent Variable } \\
\text { Travel Intention } \\
\text { (Hatay province) }\end{array}$} \\
\hline & $\begin{array}{c}\text { Std.Be } \\
\text { ta }\end{array}$ & $\begin{array}{l}\text { Sig } \\
\text { (p) }\end{array}$ & $\mathbf{t}$ & $\begin{array}{l}\text { Std. } \\
\text { Beta }\end{array}$ & $\begin{array}{l}\text { Sig } \\
\text { (p) }\end{array}$ & $\mathbf{t}$ & Std.Beta & $\begin{array}{l}\text { Sig } \\
\text { (p) }\end{array}$ & $\mathbf{t}$ \\
\hline Constant & & & & & & & & & \\
\hline Brand Image & ,319 & ,000 & 3,577 & ,229 & ,001 & 3,228 &,- 094 & 165 & $-\overline{1}$ \\
\hline $\begin{array}{l}\text { Perceived } \\
\text { Quality }\end{array}$ &,- 292 & ,003 & 2,957 &,- 007 & 992 &,- 098 & ,101 & 156 & 1,422 \\
\hline $\begin{array}{l}\text { Brand } \\
\text { Awareness }\end{array}$ & ,222 & ,008 & 2,668 & 364 & , 000 & 5,716 & ,114 & ,078 & 1,767 \\
\hline Brand Loyalty & ,534 & , 000 & 7,667 & , 189 & ,001 & 3,250 & ,660 & , 000 & $\begin{array}{l}10,50 \\
3\end{array}$ \\
\hline $\mathbf{F}$ & 124,868 & & & 95,45 & & & 128,883 & & \\
\hline $\mathbf{R}^{2}$ &, 577 & & & ,499 & & & ,582 & & \\
\hline Revised $\mathbf{R}^{2}$ &, 572 & & & $\begin{array}{r}494 \\
<0,01\end{array}$ & & & ,577 & & \\
\hline
\end{tabular}

For Adana province, all four dimensions explain the travel intent by $57.2 \%$ $\left(\right.$ corrected $\left.\mathrm{R}^{2}\right)$. Brand loyalty $(\beta=.534 ; \mathrm{p}<0.01)$ dimension has a positive effect on travel intention. Brand awareness $(\beta=.222 ; p<0.01)$ and brand image $(\beta=.319$; 
$\mathrm{p}<0.01)$ dimensions also have a positive effect on travel intention. For Adana province, $\mathrm{H} 1, \mathrm{H} 3, \mathrm{H} 4$ were accepted, but $\mathrm{H} 2$ was rejected.

For Mersin province, all four dimensions explain the travel intention by $49.9 \%$ $\left(\right.$ corrected $\left.\mathrm{R}^{2}\right)$. Brand awareness $(\beta=.364 ; \mathrm{p}<0.01)$ dimension has a positive effect on travel intention. Brand image $(\beta=.229 ; p<0.01)$ and brand loyalty $(\beta=.189 ; p<0.01)$ dimensions also have a positive effect on travel intention. For Mersin province, $\mathrm{H} 1, \mathrm{H} 3, \mathrm{H} 4$ were accepted, but $\mathrm{H} 2$ was rejected.

For Hatay province, all four dimensions explain the travel intention by $57.7 \%$ (corrected $\left.\mathrm{R}^{2}\right)$. Brand loyalty $(\beta=.664 ; \mathrm{p}<0.01)$ dimension has a positive effect on travel intention. For Hatay province, H4 was accepted, but H1, H2, H3 were rejected.

\section{Conclusion and Recommendations}

This research aimed to investigate the effect of brand image, perceived quality, brand awareness and brand loyalty dimensions, which are the components of gastronomy brand value in Adana, Mersin and Hatay provinces, on travel intention. In the light of the results of the analysis, careful examination of the expressions that come to forward and take high averages among the answers given to the propositions of gastronomy brand value components for all Adana, Mersin and Hatay provinces is very important for these provinces to be successful in gastronomy tourism. When the averages of brand value components and the answers given for travel intention for each province are examined, it seen that while the averages are above the "I Agree" (4) expression for Mersin and Hatay, some averages (brand image, perceived quality and travel intention) seen for Adana province are slightly below the "I agree" (4) expression. From this point of view, it can be said that local tourists in general have positive thoughts about brand value components about these provinces and travel intention. Necessary studies and promotions are required to be made in order to continue and increase these rates, to increase brand perception, brand awareness and brand loyalty in the provinces mentioned in the study and to increase the tourists' perceived quality and support the formation of their travel intentions. In terms of brand value of Adana cuisine, the fact that Adana's having a rich food culture and friendly food service staff, Adana cusine's being an important factor for the branding of the region, Adana's offering high quality food and Adana cuisine's having a good reputation is of great importance. The fact that tourists say they will visit Adana again for the purpose of gastronomy tourism next year and that this expression is in the first place in the dimension of travel intention also indicates that Adana may be an important gastronomic attraction center. It was observed that brand awareness and brand loyalty play a more decisive role in Adana's gastronomy brand value dimensions. Except for the perceived quality dimension, all dimensions have a positive effect on the travel intention towards Adana. For Adana, the dimension that has the strongest relationship with travel intention is the brand loyalty (.738). For Adana, in order to take place in the perception of 
tourists about gastronomy and to be visited again, it is important to carry out the works (promotions, plans, programmes, gastronomic feasts, consumer analysis etc.) that will strengthen and support these perceptions with the participation of all stakeholders. Furthermore, some efforts should be made by public and private institutions to strengthen the perceived quality concept on travel intention.

Mersin's having a relaxing food atmosphere and friendly food service stuff, Mersin's being a great opportunity to try the local cuisine, Mersin's offering delicious and high quality food, as well as the participants' who consider that the cuisine of the province has a good reputation, immediate notice of Mersin's name among other destinations (which shows that they have brand awareness) is of great importance for Mersin's brand value. It was observed that brand awareness and brand loyalty play a more decisive role in Mersin destination gastronomy brand value dimensions. Except for the perceived quality dimension, all dimensions have a positive effect on travel intention to Mersin. For Mersin province, the dimension that has the strongest relationship with travel intention is the brand awareness (.666). The strong effect of brand awareness on travel intention is an important result for Mersin. In this regard, it is necessary to continue the activities quickly in order to continue and streghten this effect on local tourists. Moreover, in order to strengthen the perceived quality concept in Mersin province on the intention to travel, studies should be carried out, plans and programmes should be developed by public and private institutions.

For Hatay, the expressions that visiting Hatay is a great opportunity to try Hatay cousine, its cousine is diverse and rich, it offers delicious food, the local food that the visitors ate in Hatay is an important factor for the branding of the region and causes the visitors to recognize and understand the local culture of Hatay, its cuisine has a good name and fame and the visitors are able to say the most famous food of Hatay came to the forefront. The visitors also stated that they generally trust Hatay cuisine and they will recommend others to visit Hatay for gastronomic tourism. It is seen that brand awareness and brand loyalty play a more decisive role in the dimensions of Hatay destination gastronomy brand value. It is important for Hatay to be a gastronomic center for its high brand loyalty and having the highest impact on travel intention (.757). However, in order for other dimensions (brand awareness, perceived quality, brand image) except for brand loyalty to have a positive effect on travel intention and to be subject to tourist visits again, the most important role in this matter is falling on the managers of Hatay who are planning and developing tourism policies. Creating effective participation of all stakeholders is also important in this matter.

This study has been the subject of the study of Adana, Mersin and Hatay provinces, which are on important routes in gastronomy. The necessity of strengthening the brand value and travel intentions of the mentioned provinces in the tourists' eyes is important. Therefore, all stakeholders in each province have important duties. The provinces in this study are also important in terms of some 
types of tourism (culture, health, belief, etc.). In this respect, these provinces, which are at the forefront of gastronomy, should integrate between other types of tourism and gastronomy tourism and increase their supporting activities (promotion, plans, programs, gastronomic feasts, consumer analysis etc.). Furthermore, all these provinces mentioned in this study should also work on issues such as receiving the creative cities network award in the field of gastronomy given by UNESCO which has recently created an important brand value in gastronomy. Hatay is one of our provinces that are entitled to receive this award, but receiving this award in provinces such as Adana and Mersin too, which are the major sources of gastronomy, will contribute greatly to promotion and support brand building. The use of gastronomic resources in brand studies and the brand image created in the minds of tourists have a great impact on revisiting and recommending that region. In this regard, work should continue rapidly in Adana, Mersin and Hatay.

The research was carried out in the aforementioned provinces because of time and cost constraints. The study is limited to the opinions of the participants taking place in the research. In order to generalize the study, comparisons and qualitative studies can be carried out in different destinations.

\section{References}

Altunışık, R., Çoşkun, R., Bayraktaroğlu, S. and Yıldırım, E. (2007). Sosyal Bilimlerde Araştırma Yöntemleri SPSS Uygulamal.. $5^{\text {th }}$ Edition, Sakarya: Sakarya Publishing.

Amira F. (2009). The Role of Local Food in Maldives Tourism: A Focus on Promotion and Economic Development. New Zealand Tourism Research Institute. Master Thesis.

Askegaard, S. and Kjeldgaard, D. (2007). Here, There, and Everywhere: Place Branding and Gastronomical Globalization in a Macromarketing Perspective. Journal of Macromarketing, 27(2), 138-147.

Boo, S., Busser, J. and Baloglu, S. (2009). A Model of Customer-Based Brand Equity and its Application to Multiple Destinations. Tourism Management 30(2), 219-231. DOI:10.1016/j.tourman.2008.06.003

Ceylan, S. (2011). Destinasyon Marka İmajı ve Pamukkale Yöresinde Bir Uygulama. International Journal of Economic and Administrative Studies. Year: 4 (7), 89-102.

Chang, R. C. Y. and Mak, A. H. N. (2018). Understanding Gastronomic İmage From Tourists' Perspective: A Repertory Grid Approach. Tourism Management, 68, 89-100. https://doi.org/10.1016/j.tourman.2018.03.004.

Chi. H. K., Huang K. C. and Nguyen, H. M. (2019). Elements of Destination Brand Equity and Destination Familiarity Regarding Travel İntention. Journal 
of Retailing and Consumer Services, 52, 1-10. https://doi.org/10.1016/j.jretconser.2018.12.012.

Chow I. H., Lau, V. P., Lo, T. W. C., Sha, Z., and Yun, H. (2007). Service quality in restaurant operations in China: Decision and Experiential-Oriented Perspectives. International Journal of Hospitality Management, 26(3), 698710. DOI: $10.1016 /$ j.ijhm.2006.07.001

Cohen, E. and Avieli, N. (2004). Food in Tourism: Attraction and Impediment. Annals of Tourism Research, 31(4), 755-778.

Çalışkan, O. (2013). Destinasyon Rekabetçiliği ve Seyahat Motivasyonu Bakımından Gastronomik Kimlik. Journal of Tourism and Gastronomy Studies, 1/2, 39-51.

Çetin, Ş. (1993). Turizm Endüstrisine Mutfak Elemanı Yetiştirmeye Yönelik Eğitim Programlarının Değerlendirilmesi. Çukurova University. Institute of Social Sciences. Educational Sciences. Unpublished Doctoral Thesis.

Çetinsöz, B. C. and Artuğer, S. (2013). Antalya İli’nin Marka Değerinin Ölçülmesine Yönelik Bir Araştırma. Anatolia: Journal of Tourism Research, 24(2), 200-210.

Fernandez, J. A. F., Cerro, A. M. C. and Mogollon, J. M. H. (2019). Potential of Olive Oil Tourism in Promoting Local Quality Food Products: A Case Study of the Region of Extremadura, Spain. Heliyon, 5(10), 1-8. https://doi.org/10.1016/j.heliyon.2019.e02653.

Hacıoğlu, N., Girgin G. K., and Giritlioğlu İ. (2009). Yiyecek-İçecek İşletmelerinin Pazarlama Faaliyetlerinde Yöresel Mutfakların Kullanımı Balıkesir Örneği. III. National Gastronomy Symposium Papers. Antalya.

Hall, M. and Sharples, L. (2003). The Consumption of Experiences or the Experience of Consumption? An Introduction to the Tourism of Taste. Food Tourism Around the World, London: Butterworth Heinemann, 1-25.

Horng, J-S, Liu, C-H., Chou, H-Y. and Tsai, C-Y. (2012). Understanding the impact of culinary brand equity and destination familiarity on travel intentions. Tourism Management, 33(4), 815-824. DOI: 10.1016/j.tourman.2011.09.

Kao, M. C., Patterson, I., Scott, N. and Li, C. K. (2008). Motivations and Satisfactions of Taiwanese Tourists who Visit Australia: An Exploratory Study. Journal of Travel \& Tourism Marketing, 24(1), 17-33. http://dx.doi.org/10.1300/J073v24n01_02.

Karim, A. S. and Chi, C. G. Q. (2010). Culinary Tourism as a Destination Attraction: an Empiricial Examination of Destinations Food İmage. Journal of Hospitality Marketing and Management, 19(6), 531-555. 
Kivela, J. and Crotts, J. C. (2006). Tourism and Gastronomy: Gastronomy's Influence on How Tourists Experience a Destination. Journal of Hospitality \& Tourism Research, 30(3), 354-377. https://doi.org/10.1177/1096348006286797.

Kocaman, S. and Güngör, İ. (2012). Destinasyonlarda Müşteri Temelli Marka Değerinin Ölçülmesi ve Marka Değeri Boyutlarının Genel Marka Değeri Üzerindeki Etkileri: Alanya Destinasyonu Örneği. International Journal of Alanya Faculty of Business. 4(3), 143-161.

Kozak, N. (2008). Turizm Pazarlaması, $2^{\text {nd }}$ Edition, Ankara: Detay Publishing.

Küçükaltan, G. (2009). Küreselleşme Sürecinde Gastronomide Yöresel Tatların Turistlerin Destinasyon Tercihlerine ve Ülke Ekonomilerine Etkileri. 3rd National Gastronomy Symposium. April 17-18, 2009, Antalya.

Lai, M. Y., Khoo-Lattimore, C. and Wang, Y. (2017). Food and Cuisine Image in Destination Branding: Toward a Conceptual Model. Tourism and Hospitality Research, 19(2), 238-251

Lai, M. Y., Khoo-Lattimore, C. and Wang, Y. (2018). A Perception Gap Investigation Into Food and Cuisine Image Attributes for Destination Branding from the Host Perspective: The Case of Australia. Tourism Management, 69, 579-595. https://doi.org/10.1016/j.tourman.2018.06.033.

Ling, L. Q., Karim, M. S. A., Othman, M., Adzahan, N. M. and Ramachandran, S. (2010). Relationships Between Malaysian Food Image, Tourist Satisfaction and Behavioural Intention. World Applied Sciences Journal, 10, 164-171.

Mckercher, B., Okumuş, F., and Okumuş, B. (2008). Food Tourism as a Viable Market Segment: It's all How You Cook the Numbers. Journal of Travel \& Tourism Marketing, 25(2),137- 148.

Molina, M. A. R., Jamilena, D. M. F., García, S. D. B. and Castaeda, A. (2019). Destination Brand Equity-Formation: Positioning by Tourism Type and Message Consistency. Journal of Destination Marketing \& Management, 12, 114-124. https://doi.org/10.1016/j.jdmm.2019.03.010.

Murphy, L., Benckendorff, P. and Gianna, M. (2007). Destination Brand Personality: Visitor Perceptions of a Regional Tourism Destination. Tourism Analysis, 12(5-6), 419-432. https://doi.org/10.3727/108354207783227948.

Pineda, J. M. B., Florencioa, B. P., Hurtadob, J. M. R. and Roldan, L. S.(2019). Gastronomic Experience as a Factor of Motivation in the Tourist Movements. International Journal of Gastronomy and Food Science, 18, 1-10. https://doi.org/10.1016/j.ijgfs.2019.100171.

Rand, G. E. and Heat, E. (2006) Towards a Framework for Food Tourism as an Element of Destination Marketing. Current Issues in Tourism, 9(3), 206-234. 
Rimmington, M. and Yüksel, A. (1998). Tourist Satisfaction and Food Service Experience: Results and İmplications of an Empirical Investigation. Anatolia, 9(1), 37-57. DOI:10.1080/13032917.1998.9686958

Ryan, J. and Casidy, R. (2018). The Role of Brand Reputation in Organic Food Consumption: A Behavioral Reasoning Perspective. Journal of Retailing and Consumer Services, 41, 239-247. https://doi.org/10.1016/j.jretconser.2018.01.002.

Sanchez-Canizares, S. M. and Lopez-Guzman, T. (2012). Gastronomy as a Tourism Resource: Profile of the Culinary Tourist. Current Issues in Tourism, 15(3), 229-245. https://doi.org/10.1080/13683500.2011.589895.

Selwood, J. (2003) The Lure of Food: Food as an Attraction in Destination Marketing in Manitoba, Canada, Michael Hall (Ed), Food Tourism Around the World: Management of Development and Markets, 178- 180, Great Britain: Elseiver.

Sims, R. (2009). Food, Place and Authenticity: Local Food and the Sustainable Tourism Experience. Journal of Sustainable Tourism, 17(3), 321-336. https://doi.org/10.1080/09669580802359293.

Yaprakl1, T. Ş. and Kara, E. (2015). Marka Değeri Bileşenlerinin Müşteri Temelli Ölçümlenmesi: Kahramanmaraş Dondurma Sektörüne Yönelik Bir Uygulama. Kahramanmaraş Sütçü Imam University. Journal of Faculty of Economics and Administrative Sciences, 5(2), 133-154.

Yu, C-E. and Sun, R. (2019). The Role of Instagram in the UNESCO's Creative City of Gastronomy: A Case Study of Macau. Tourism Management, 75, 257268. https://doi.org/10.1016/j.tourman.2019.05.011.

Wang, J., Tao, J. and Chu, M. (2019). Behind the Label: Chinese Consumers' Trust in Food Certification and the Effect of Perceived Quality on Purchase Intention. Food Control, $\quad 108, \quad$ 2-10, https://doi.org/10.1016/j.foodcont.2019.106825.

Zeithaml, V. A. (1988). Consumer Perceptions of Price, Quality, and Value: A Means-End Model and Synthesis of Evidence. Journal of Marketing, 52(3), 222. DOI: $10.1177 / 002224298805200302$. 